\title{
UPAYA PENINGKATAN MUTU PENDIDIKAN PESANTREN TRADISIONAL DI ERA MILLENIAL
}

\author{
Oleh:
}

Ahmad Husen Ma'ruf \& Jasminto

Universitas Hasyim Asy'ari Tebuireng Jombang - Indonesia

Email: ahmadmaruf544@gmail.com

Email: jasminto2010@gmail.com

\begin{abstract}
This article aims to express a data related the quality increasing effort of old islamic boarding school education at Pesantren Tarbiyatunnasyiin Paculgowang Jombang. This research uses qualitative research method to get a data through observation, interview and documentation. Whereas data analysis technique is using data reduction procedure, data presentation and verification. The results of this research study are; the first, the education quality of Tarbiyatunnasyiin islamic boarding school is kept well by a proof namely there are input which is run throngh efficient and effective process and output resulted throngh that good education process. This islamic boarding school can graduated its graduates who are not only clever on religious knowledges but also clever on the other sectors. Beside of that its education legality has beeb acknowledged by the government. The second, on increasing its education quality, Tarbiyatunnasyiin islamic boarding school makes some programs which are arranged and done by the organizers of islamic boarding school efficiently and effectively and it is also supported by sufficing means and environment.
\end{abstract}

\begin{abstract}
Abstrak
Artikel ini bertujuan mengungkapkan data terkait upaya peningkatan mutu pendidikan pesantren tradisional di pesantren Tarbiyatunnasyiin Paculgowang Jombang. Penelitian ini menggunakan metode penelitian kualitatif untuk mendapatkan suatu data melalui observasi, wawancara dan dokumentasi. Sedangkan teknik analisis data yaitu menggunakan prosedur reduksi data, penyajian data, dan verifikasi. Hasil dari studi penelitian ini adalah Pertama, mutu pendidikan pesantren Tarbiyatunnasyiin terjaga dengan baik dengan bukti adanya input yg dijalankan melalui proses yang efektif dan efisien serta output yang dihasilkan melalui proses pendidikan yang baik tersebut. Pesantren ini dapat meluluskan lulusannya yang tidak hanya mahir dalam ilmu agama, melainkan juga terampil dalam bidang-bidang yg lain. Disamping itu legalitas pendidikannya sudah diakui oleh pemerintah. Kedua, dalam meningkatkan mutu pendidikanya, pesantren Tarbiyatunnasyiin membuat beberapa program yang disusun dan dilaksanakan oleh para pengurus pesantren dan Madrasah secara efektif dan efisien serta didukung oleh lingkungan dan sarana yang memadai.
\end{abstract}

Kata Kunci: Mutu Pendidikan, Pesantren Salaf, Era Millenial 


\section{A. PENDAHUluan}

Di Era Milenial ini, tantangan lembaga pendidikansemakin fundamental. Dikarena kita tidak hanya menghadapi tantangan budaya global yang datang dari barat, tetapi juga dihadapkan pada suatu kenyataan yang memaksa pesantren khawatir dalam mempertahankan tradisi mereka yang sudah bertahan selama berabad-abad. Oleh karenanya, perlu dilakukan upaya dan gerakan positif untuk menghindari jebakan budaya global yang sengaja ingin menghantam tatanan pendidikan pesantren. ${ }^{1}$

Indrakusuma mengatakan bahwa masalah pendidikan adalah merupakan masalah yang sangat penting dalam suatu kehidupan.Karena sebagian besar maju mundurnya suatu Negara dipengaruhi oleh pendidikan di negara tersebut. Agar dapat merealisasikan pendidikan yang lebih baik, maka dalam hal ini pendidikan harus berupaya meningkatkan mutu pendidikannya.Dalam Hal ini Allah SWT berfirman dalam surat ArRa'd ayat 11:

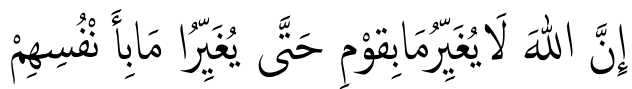

"Sesungguhnya Allah tidak merubah keadaan sesuatu kaum sehingga mereka merubah keadaan yang ada pada diri mereka sendri". ${ }^{2}$

Ayat tersebut memberikan keterangan bahwasannya Allah akan mengubah kondisi sebuah masyarakat atau kaum, kalau mereka mau melakukan perubahan. Dalam hal ini ialah para penyelenggara lembaga pendidikan pesantren.Sedangkan perubahan yang dikehendaki adalah perubahan kearah yang lebih baik.

Menyadari akan hal tersebut, sebagian besar pesantren mengembangkan pendidikan guna mencoba memperbaiki dirinya dengan suatu kemajuan. Dalam keadaan persaingan yang demikian itu, maka setiap penyelenggara dan pengelola pendidikan hendaknya mengupayakan

\footnotetext{
${ }^{1}$ Mohammad Takdir, Modernisasi Kurikulum Pesantren (Yogyakarta: Ircisod, 2018), hlm. 116

2 Departemen Agama RI, Al-Qur'an dan Terjemahnya (Al-Bayan), (Semarang: Asy-Syifa', 2001), hlm. 665
} 
peningkatan pendidikan yang berorientasikan pada peningkatan mutu atau quality sebagai produk pendidikan.. ${ }^{3}$

Zani berpendapat bahwa, pendidikan yang bermutu adalah pendidikan yang lulusannya sesuai dengan kebutuhan yang adadi masyarakat serta sesuai dengan kriteria pada pengguna lulusan. ${ }^{4}$

Berkaitan dengan permasalahan di atas, pesantren ini banyak berbena dalam menata sistem pendidikan dan melengkapi komponenkomponen pendidikan guna mencapai tujuan pendidikannya, dengan harapan pesantren ini dapat mencetak manusia yang berprestasi dan berakhlak mulia.

Salah satu upaya dalam pembenahan tersebut adalah melengkapi buku-buku perpustakaan, mengadakan seminar keagamaan, mengadakan bimbingan terkait mata pelajaran di Madrasah yang dilakukan pada setiap hari selain hari senin dan jum'at, diskusi keilmuan selain hari jum'at dan lain sebagainya. Hal ini sebagaimana pendapat yang diutaran oleh Rhohani Sidiq bahwa pesantren dituntut untuk melakukan perubahan dengan menyusun ulang sistem pendidikannya mulai dari kurikulum, silabus dan sebagainya. Dengan tujuan agar pesantren dapat menjawab tuntutan kebutuhan masyarakat. ${ }^{5}$

\section{B. KAJIAN PUSTAKA \\ 1) Mutu Pendidikan}

Dalam konteks pendidikan, pendidikan dapat dikatakan bermutu apabila dapat memenuhi input, proses, output dan dampak. ${ }^{6}$ Umiarso dan Zazin (dalam Muin) mengemukakan bahwa pendidikan bermutu adalah merupakan pendidikan yang menunjukkan kemampuannya dalam memuaskan kebutuhan dari konsumen atau pelanggan pendidikan(santri, orangtua santri dan masyarakat). Dengan kata lain, lembaga pendidikan sebagai institusi jasa. ${ }^{7}$

\footnotetext{
${ }^{3}$ Abuddin Nata, Manajemen Pendidikan (Jakarta: Kencana Prenada Media Group, 2003), hlm. 380

${ }^{4}$ Nur zani, Gerakan Menata Mutu Pendidikan (Jogjakarta: Ar-Ruzz Media, 2016), hlm 66-67

${ }^{5}$ Rohani Shidiq, Gus Dur Penggerak Dinamisasi Pendidikan Pesantren (Yogyakarta: Istana Publishing, 2015), hlm. 165

${ }^{6}$ Yusuf Umar, Manajemen Pendidikan Madrasah Bermutu (Bandung: PT Rafika Aditama, 2016), hlm. 27

${ }^{7}$ Abd. Muin, "Upaya Peningkatan Mutu Pendidikan di Pondok Pesantren Hj. Haniah Maros Sulawesi Selatan", Edukasi, 2 (Mei, 2012), hlm. 233
} 
Dalam pelaksanaan pendidikan, pesantren yang memakai teori TQM untuk menjaga kebermutuan dalam pendidikannyaharus memerhatikan lima hal pokok, yaitu sebagai berikut; 1) perbaikan secara terus-menerus, 2) menentukan standar mutu, 3) perubahan kultur, 4) perubahan organisasi, 5) menjaga hubungan dengan pelanggan. ${ }^{8}$

Dari uraian tersebut di atas, dapat disimpulkan bahwa mutu pendidikan adalah serangkaian cara atau metode dalam mengupayakan penjamin kualitas pendidikan berkelanjutan dalam segi input, proses maupun output untuk mencapai tujuan pendidikan.

Upaya peningkatan mutu pendidikan pesantren saat ini lebih cocok menggunakan teori Total Quality Managemen (TQM). Karena mutu dalam konteks TQM adalah merupakan suatau perencanakan perubahan serta pengatur agenda untuk menghadapi permasalahan eksternal yang berlebihan yang diwujudkan dalam bentuk pelaksanaan atau proses. Prinsip dasar dalam TQM adalah bahwa pelanggan dan kepentingannya harus diutamakan. ${ }^{9}$

\section{2) Pendidikan Pesantren}

Istilah pesantren di Jawa dan Madura lebih dikenal dengan nama pondok. Istilah "pondok" berasal dari bahasa Arab funduq, yang berarti asrama. ${ }^{10}$ Sedangkan pesantren senantiasa disertakan dibelakang kata "pondok", sehingga menjadi pondok pesantren.

Menurut Kamus Besar Bahasa Indonesia.Pesantren berarti, "tempat murid-murid belajar mengaji..." Sedangkan pendapat lain mengatakan bahwa kata "pesantren" berasal dari kata dasar Santri mendapat walan pe dan akhiran an digabung menjadi pesantrian, yang mirip dengan kata pesantren yang mengandung makna sebagai tauhid. ${ }^{11}$

\footnotetext{
${ }^{8}$ Nur zani, Gerakan Menata Mutu Pendidikan (Jogjakarta: Ar-Ruzz Media, 2016), hlm. 64

9 Edward Sallis, Total Quality Management In Education, terj. Ahmad Ali Riyadi dan Fahrurrozi, (Cet, IX; Jogjakarta: Ircisod, 2010), hlm. 23

${ }^{10}$ Mohammad Takdir, Modernisasi Kurikulum Pesantren (Cet; 1, Yogyakarta: Ircisod, 2018), hlm. 22

${ }^{11}$ Mohammad Takdir, Modernisasi, hlm. 43
} 
Terlepas dari asal-usul kata itu berasal dari mana, yang jelas ciriciri umum keseluruhan pesantren yaitu lembaga pendidikan Islam yang asli Indonesia, yang pada saat ini merupakan warisan kekayaan bangsa Indonesia yang terus berkembang. Bahkan pada Era millennium ini menjadi salah satu penyangga yang sangat penting bagi kehidupan berbangsa dan bernegara. ${ }^{12}$.

Mengenai pengertian pesantren Zamakhsyari Dhofir berpendapat bahwa pesantren adalah sebuah asrama pendidikan Islam tradisional di mana siswa dan gurunya tinggal bersama-samaserta belajar di bawah bimbingan seorang guru "kiyai". Serta terpenuhinya elemenelemen pesantren seperti: masjid untuk beribadah, ruangan untuk belajar dan kegiatan keagamaan dan sebagainya. ${ }^{13}$

Berdasarkan sosio-historis, pesantren sebagai lembaga pendidikan keagamaan yang telah berusia relatif tua lahir dengan tujuan untuk mengajarkan, menyampaikan dan mengembangkan nilainilai ajaran Islam sesuai dengan misi awalnya (tafaqquh fi al-din) ${ }^{14}$

Sedangkan Gus Dur dalam Rohani Shidiq mengemukakan, bahwa tujuan pesantren (sebagai inti dari Pendidikan Isalm) adalah untuk mencetak kader guna mengabdi kepada masyarakat sebagai pendidik agama dan mengembangkan kewiraswastaan, bukan generasi yang berorientasi menjadi pegawai. Tujuan pendidikan pesantren secara keseluruhan adalah mencetak kader guna mengabdi kepada masyarakat.Kader berarti pula para penerus dan pewaris tanah air dan harus mau mengabdi untuk kepentingan bangsa, kader yang mandiri dan mampu berdikari, baik secara ekonomi, sosial, budaya dan politik. $^{15}$

Sedangkan ciri-ciri atau karakteristik pesantren adalah sebagai mana yang di utarakan oleh Samsul Nizar bahwa pesantren memiliki karakteristik yang berbeda dari lembaga pendidikan yang lain, diantaranya adalah:

1) Segi materi dan metode pengajaran

12 Zamakhsyari dhofir, Tradisi Pesantren: studi pandangan hidup kiyai dan visinya mengenai masa depan Indonesia (Jakarta: LP3ES, 2011), hlm. 41

13 Zamakhsyari dhofir, Tradisi Pesantren, hlm. 79

${ }_{14}$ Abd.Muin, "Upaya Peningkatan Mutu Pendidikan di Pondok Pesantren Hj. Haniah Maros Sulawesi Selatan", Edukasi, 2 (Mei, 2012), hlm. 235

15 Rohani Shidiq, Gus Dur Penggerak Dinamisasi Pendidikan Pesantren (Yogyakarta: Istana Publishing, 2015), hlm. 54 
JURNAL PIWULANG, Vol. 2 No. 1 September 2019, 49-63

Pesantren pada mulanya,hanya mengajarkan materi agama.Adapun metode yang digunakan dalam pesantren ialah model wetonan, yakni metode dimana santri duduk disekeliling kiyai, dan santri menyimak kitab dan juga mencatat jika ada yang perlu dicatat. Metode sorogan, yakni metode di mana santri menghadap kepada kiyai satu persatu dengan membawa kitab, metode ini dirasa paling sulit dibanding dengan metode yang lainnya.

2) Segi jenjang pendidikan

Dalam pesantren ditandai pada penguasaan dan pemahaman kitab-kitab klasikyang telah ditetapkan

3) Segi fungsi pesantren

Sebagai model pendidikan tertua di Indonesia Pesantren memiliki beberapa fungsi yang sangat fundamental diantaranya: lembaga pendidikan, lembaga sosial, dan lembaga penyiaran keagamaan.

4) Kehidupan santri dan kiyai

Berdirinya pesantren bermula dari adanya seorang kiyai yang menetap yang kemudian di ikuti oleh seorang santri yang ingin belajar dan juga bermukim bersama kiyai.Sedang biaya kehidupan dan pendidikannya ditanggung bersama oleh para santri dan dukungan dari masyarakat di sekitarnya.Hal demikian memungkinkan bagi pesantren untuk menstabilkan kehidupannya tanpa adanya pengaruh dari ekonomi di luar. ${ }^{16}$

Ciri-ciri tersebut gambaran dari pesantren yang masih murni.Seiring dengan perkembangan zaman pesantren telah terdorong untuk melakukan perubahan terus menerus.Akibat dari perubahan tersebut, pesantren saat ini dibedakan menjadi beberapa bentuk.Menurut Zamakhsari Dhofir bentuk dan model pesantren dapat digolongkan menjadi dua yaitu pesantren salaf dan pesantren khalaf. Pesantren salaf yaitu pesantren yang pendidikannya tetap kokoh mempertahankan materi dan metode pengajaran klasik. ${ }^{17}$

\footnotetext{
${ }^{16}$ Samsul Nizar, Sejarah Pendidikan Islam, Menelusuri Jejak Sejarah Pendidikan Era Rasulullah Sampai Indonesia,(Jakarta: Kenjana, 2009), hlm. 287-288

${ }_{17}$ Imam Machali dan Ara Hidayat, The Hand Book Of Education Management (Jakarta: Prenadamedia Group, 2016), hlm. 360
} 
Sedangkan menurut Samsul Nizar pesantren dapat digolongkan menjadi tiga bentuk diantaranya:pertama, pesantren tradisional, yaitu pesantren yang tidak mengalami transformasi atau inovasi dalam sistem pendidikannya.Kedua, pesantren tradisional, pada pesantren ini dalam pendidikannya telahmemulai mengadopsi sistem pendidikan modern, hannya saja tidak secara keseluruhan.Ketiga, pesantren modern.Pesantren ini telah mengalami transformasi yang signifikan baik dalam sistem pendidikannya maupun unsur-unsur kelembagaannya. ${ }^{18}$

Dalam kaitannya dengan penelitian ini, peneliti memfokuskan pada model pesantren salaf atau tradisional dalam mengkaji mutu pendidikannya, karena seiring dengan perkembangan zaman,pesantren salaf atau tradisional dituntut untuk mampu mengembangkan ilmu agama, dan menyinergikan dengan kemajuan ilmu pengetahuan modern sehingga nantinya lulusan pesantren dapat menjadi suri teladan bagi pengembangan tatanan kehidupan masyarakat yang religius dan Islami.

Oleh karenanya, setiap penyelenggara pendidikan termasuk pendidikan pesantren adalah wajib hukumnya melakukan perubahan menuju peningkatan mutu pendidikan yang lebih baik, baik dengan menggunakan sistem TQM atau lain sebagainya. Dengan cara demikian, diharapkan akan terwujud suatu pendidikan pesantren atau madrasah yang bermutu, sehingga pesantren tetap akan mampu bersaing dalam mempertahankan konsistensinya dalam hal pendidikan dan tetap menjadi pilihan masyarakat.

\section{METODE PENELITIAN}

Pendekatan penelitian ini adalah kualitatif studi kasus. Menurut Arikuntopenelitian studi kasus, yaitu suatu penelitian yang dilakukan secara mendalam terhadap suatu gejala tertentu. ${ }^{19}$ Dalam penelitian ini peneliti lebih menekankan pada peningkatan mutu pendidikan pesantren di pesantren Tarbiyatunnasyiin Paculgowang Jombang. Dalam hal penelitian ini, setidaknya diperlukan tiga macam metode pengumpulan data, yaitu metode observasi, metode wawancara, dan metode

\footnotetext{
${ }^{18}$ Samsul Nizar, Sejarah Pendidikan Islam, Menelusuri Jejak Sejarah Pendidikan Era Rasulullah Sampai Indonesia(Jakarta: Kenjana, 2009), hlm. 289-290

${ }^{19}$ Suharsimi Arikunto, Prosedur Penelitian (Jakarta: PT. Rineka Cipta, 2013), hlm. 185
}

- Ah. Husain Ma'ruf \& Jasminto - 55 
dokumentasi. Teknik Analisis Data, setelah data terkumpul semua, maka langkah selanjutnya adalah melakukan analisa data. Dalam penelitian ini, peneliti menggunakan model Miles dan Huberman yaitu pengumpulan data, reduksi data, penyajian data, dan penakiran kesimpulan dan verifikasi. $^{20}$

Pengecekan keabsahan data digunakan untuk memperoleh data yang valid dan dapat dipertanggung jawabkan. Teknik pemeriksaan data atau uji keabsahan data ini dapat dilakukan dengan beberapa cara. Menurut Moleong, pemeriksaan keabsahan data dapat ditempuh dengan perpanjangan pengamatan, ketekunan pengamatan, triangulasi, pengecekan keanggotaan, uraian rinci, dan auditing. ${ }^{21}$

\section{HASIL PENELITIAN}

1) Mutu Pendidikan Pesantren Tarbiyatunnasyiin Paculgowang Jombang di Era Milenial

Mutu pendidikan saat ini sedang menjadi topik yang hangat dibicarakan oleh banyank kalangan. Dikarenakan mutu pendidikan merupakan sesuatu yang sangat penting yang harus dijaga oleh suatu lembaga pendidikan, sebagai tolak ukur dari kualitas suatu keberhasilan lulusannya dalam merealisasikan proses pembelajaran yang telah dilaluinya. Disamping itu, mutu pendidikan yang berkualitas dapat menentukan kualitas manusia yang baik.Menyadari akan hal tersebut, semua lembaga pendidikan baik formal maupun non formal di zaman ini berlomba-lomba dalam mengupayakan peningkatan pendidikan yang berorientasikan pada peningkatan mutu pendidikan sebagai produk pendidikan.

Kesadaran akan pentingnya mutu pendidikan dalam menentukan kualitas yang hendak dicapainya, pesantren banyak melakukan pembenahan guna menjaga mutu lulusannya, sesuai dengan Pasal 91 ayat 1 Peraturan Pemerintah Nomor 19 tahun 2005 Tentang Standar Nasional Pendidikan yang berbunyi "setiap satuan pendidikan

${ }^{20}$ M. Djunaidi Ghony dan Fauzan Almanshur, Metode Penelitian Kualitatif (Jogjakarta: Ar-Ruzz Media, 2012), hlm. 308

${ }^{21}$ Lexy. J. Moleong, Metode Penelitian Kualitatif (Bandung: Remaja Rosdakarya, 2016), hlm. 327 
pada jalur formal dan nonformal wajib melakukan penjaminan mutu pendidikan".22

Berdasarkan hasil penelitian yang diperoleh peneliti saat melakukan penelitian mengenai upaya peningkatan mutu pendidikan pesantren salaf di pesantren Tarbiyatunnasyiin Paculgowang bahwa dalam mengukur mutu pendidikan dibutuhkan pemahaman dalam beberapa aspek yaitu aspek input, proses dan output pendidikannya.

Hal ini sesuai dengan teori yang dikemukakan oleh Yusuf Umar bahwa dalam konteks pendidikan, mutu mengacu pada input, proses, output dan dampak. Mutu inputdikatakan bermutu apabila memenuhi beberapa aspek, pertama, dilihat dari baik tidaknya situasi dan kondisi input sumber daya manusia. Kedua, memahami atau tidak mengenai kriteria sekolah dan ketiga, kriteria input berupa perangkat lunak dapat terpenuhi atau tidak. Serta yang keempat, memenuhi mutu input yang sifatnya adalah berupa harapan dan kebutuhan.

Mutu proses pembelajaran,pendidikan dikatakan bermutu apabila sumber daya yang ada mampu mengolah multijenis input dan kondisi. Hal ini dimaksud untuk mencapai nilai tambahan bagi siswa.

Sedangkan output pendidikan dapat dikatakan bermutu, apabila mampu menghasilkan keunggulan akademik dan ekstrakulikuler bagi siswa untuk satu jenjang pendidikan. ${ }^{23}$

Sebagai salah satu model pendidikan di Indonesia, Pesantren Tarbiyatunnasyiin juga memiliki standar input pendidikan yang ingin dicapainya, standarinput pesantren ini antara lain: pencapaian dari segi akhlaqul karimah,dan pemahaman terhadap kitab-kitab klasik "kitab kuning", untuk mewujudkan visi dan misi pesantren yang ingin dicapainya yaitu membentuk pribadi Muslim yang berilmu. Standar ini berdasarkan atas azas "al-muhafadhoh 'alal qadimil ashlah wal ahdzu min jadidin nafi'” yaitu menjaga tradisi lama yang lebih baik dan menambah ilmu pengetahuan yang baru yang bermanfaat.

Sedangkan untuk merealisasikan standar input pesantren Tarbiyatunnasyiin melakukan banyak cara, diantarannya:

a. Dilingkungan Madrasah

${ }^{22}$ Imam Machali dkk, The Hand Book Of Education Management (Teori Dan Praktik Pengelolaan Sekolah/Madrasah di Indonesia), (Jakarta: Prenada Media Group, 2016), hlm. 545 ${ }^{23}$ Yusuf Umar, Manajemen Pendidikan Madrasah Bermutu (Bandung: PT Rafika Aditama, 2016), hlm. 27 
Di Madrasah disamping para santri belajar di dalam kelas dengan dipandu oleh seorang guru, para santri juga mendapatkan tambahan waktu dalam memahami pelajarannya, yaitu melalui kegiatan Musyawarahatau diskusi yang dibimbing oleh dua sampai tiga guru.

Hal ini bertujuan untuk melatih para santri agar berani vokal (mengajukan pendapat) dalam memecahkan problematika keagamaan dalam realita kehidupan Masyarakat sesuai dengan kaidah-kaidah hukum syara'.

b. Dilingkungan Pesantren

Disamping santri mendapatkan pengajaran ilmu di Madrasah, para santri juga mendapatkan fasilitas belajaran yang dikoordinir oleh departemen pendidikan pesantren seperti belajar wajib, gunanya kegiatan ini yaitu sebagai penguat dalam memahami dan memperdalam sebuah fan keilmuan dengan metode pengajaran yang berbeda-beda dari setiap pembimbing, salah satu metode yang sering dilakukan adalah metode sorogan.

Untuk Output dari proses yang telah dilaluinya, pesantren ini mampu melahirkan keunggulan akademik dan ekstrakulikuler. Keunggulan akademik yang dimiliki oleh pesantren Tarbiyatunnsyiin yaitu berupa pemahaman dan penguasaan dalam kitab-kitab kuning, sedangkan keuggulan dalam bidang ekstrakulikuler yang dimilikinya adalah ketrampilan dalam baca kitab kuning, seni hadrahi dan juga seni baca Al-Qur'an atau "Qori”".

Melihat dari dari paparan analisis data di atas maka pesantren Tarbiyatunnasyiin sudah dikatakn bermutu dalam pendidikannya. Hal ini dikarenakan telah terpenuinya segala aspek baik dari aspek input, proses maupun outpunya.

2) Upaya Peningkatan Mutu Pendidikan Pesantren Tarbiyatunnasyiin di Era Milenial

Sebagai upaya yang dilakukan oleh pesantren Tarbiyatunnasyiin dalam meningkatkan mutu pendidikannya adalah dengan cara menyusun beberapa program diantaranya:

a. Program Harian

Program harian ini, meliputi anjuran bagi para santri untuk melaksanakan tugas dan kewajibannya, diantarannya ialah sholat 
jama'ah, takhassus Al-Qur'an, dan pengkajian kitab-kitab terkail ilmu agama, dan lain sebagainya. Kegiatan-kegiatan tersebut dimaksudkan untuk menanamkan sifat disiplin terhadap peserta didik untuk menjalankan tugas dan kewajibannya serta mengasah kecakapan dalam membaca dan memahami kitab kuning.

Tujuan dari program tersebut ialah supaya para santri dapat menghargai waktu dan memiliki pemahaman keilmuan dari kitabkitab kuning dengan sempurna dan pada akhirnya para santri dapat mempraktekkan hal-hal tersebut dimanapun mereka berada.

b. Program Mingguan

Program mingguan ini sengaja dibuat untuk membantu para santri dalam meningkatkan mengembangkan potensi dan bakat mereka melalui kegiatan-kegiatan ekstrakulikuler yang dirancang oleh pengurus bidang pendidikan yang dibantu oleh bidang kesenian dan olah raga seperti: pelatihan banjari, da'wah, qiro'ah, bola voli, sepak bola, bulu tangkis, tenis meja dan lain sebagainya.

Hal ini bertujuan agar santri mempunyai mental yang kuat terutama ketika menunjukkan bakat ketrampilannya dihadapan khalayak umum serta ditunjang dengan kesehatan jasmani.

c. Program Bulanan

Dalam program ini, setiap bulan para pengurus mengadakan pertemuan dengan para santri untuk diberi wawasan pengetahuan melalui seminar-seminar yang diselenggarakan oleh pengurus pesantren, dan juga mengagendakan pengajian setiap jum'at legi yang diisi langsung oleh pengasuh.

Hal ini bertujuan untuk mengembangkan dan memperluas pandangan para santri terhadap nilai-nilai keagamaan dan kenegaraan sebagai upaya dalam menanamkan nilai-nilai agama dan nasonalisme pada diri para santri.

d. Membuat Program Tahunan

Pihak pesantren mengagendakan program tahunan ini yang dikemas dalam bentuk kegiatan syafari da'wah bagi para santri tingkat akhir sebagi syarat kelulusan purna siswa jenjang akhir yakni Ma'had Aly.

Hal ini bertujuan sebagai upaya pelatihan bagi para santri untuk mengamalkan ilmu yang telah diperoleh dan serta pengabdian terhadap masyarakat. 


\section{E. PENUTUP}

Dari paparan di atas, dapat disimpulkan 2 hal utama: Pertama, mutu pendidikan pesantren Tarbiyatunnasyiin terjaga dengan baik dengan bukti adanya input yg dijalankan melalui proses yang efektif dan efisien serta output yang dihasilkan melalui proses pendidikan yang baik tersebut. Pesantren ini dapat meluluskan lulusannya yang tidak hanya mahir dalam ilmu agama, melainkan juga terampil dalam bidang-bidang yg lain. Disamping itu legalitas pendidikannya sudah diakui oleh pemerintah. Kedua, dalam meningkatkan mutu pendidikanya, pesantren Tarbiyatunnasyiin membuat beberapa program yang disusun dan dilaksanakan oleh para pengurus pesantren dan Madrasah secara efektif dan efisien serta didukung oleh lingkungan dan sarana yang memadai.

\section{DAFTAR PUSTAKA}

Al-Qur'an dan Terjemahnya (Al-Bayan). Departemen Agama RI 2001. Semarang: Asy-Syifa'.

Arikunto, Suharsimi. 2013. Prosedur Penelitian. Jakarta: PT. Rineka Cipta.

Dhofir, Zamakhsyari. 2011. Tradisi Pesantren : studi pandangan hidup kiyai dan visinya mengenai masa depan Indonesia. Jakarta: LP3ES.

Ghony, M. Djunaidi dan Fauzan Almanshur. 2012.Metode Penelitian Kualitatif. Jogjakarta: Ar-Ruzz Media.

J. Moleong, Lexy. 2016.Metode Penelitian Kualitatif.Bandung: Remaja Rosdakarya.

Machali, Imam dkk. 2016. The Hand Book Of Education Management (Teori Dan Praktik Pengelolaan Sekolah/Madrasah di Indonesia). Jakarta: Prenada Media Group.

Muin, Abd. "Upaya Peningkatan Mutu Pendidikan di Pondok Pesantren Hj. Haniah Maros Sulawesi Selatan", Edukasi. 2012.

Nata, Abuddin. Manajemen Pendidikan. Jakarta: Kencana Prenada Media Group. 2003.

Nizar, Samsul. Sejarah Pendidikan Islam, Menelusuri Jejak Sejarah Pendidikan Era Rasulullah Sampai Indonesia. Jakarta: Kenjana. 2009.

Sallis, Edward.2010. Total Quality Management InEducation, terj. Ahmad Ali Riyadi dan Fahrurrozi,Cet, IX; Jogjakarta: Ircisod. 
JURNAL PIWULANG, Vol. 2 No. 1 September 2019, 49-63

Shidiq, Rohani. 2015.Gus Dur Penggerak Dinamisasi Pendidikan Pesantren. Yogyakarta: Istana Publishing.

Takdir, Mohammad. Modernisasi Kurikulum Pesantren. Yogyakarta: Ircisod. 2018.

Umar, Yusuf. Manajemen Pendidikan Madrasah Bermutu. Bandung: PT Rafika Aditama. 2016.

Zani, Nur. Gerakan Menata Mutu Pendidikan. Jogjakarta: Ar-Ruzz Media. 2016. 